Folia Linguistica Historica XXII/1-2 pp. 103-135

(C) Societas Linguistica Europaea

\title{
SOURCES OF MARKEDNESS IN LANGUAGE STRUCTURES
}

\author{
WOLFGANG U. DRESSLER - KATARZYNA DZIUBALSKA-KOŁACZYK - \\ ROSSELLA SPINA
}

\section{Markedness: theoretical background}

The basic question of our paper is why and how marked phenomena arise in a natural language. The main approach to answering it is to inspect external evidence mainly from diachrony, but also first language acquisition and socio-cultural variation. The theoretical frameworks are naturalness theory, a building-block model of complexity theory, a semiotic metatheory and the epistemology of functionalism (cf. Dressler 1995, Dressler - Dziubalska-Kołaczyk 1994).

Within naturalnes theory, as elaborated for both Natural Phonology and Natural Morphology in Dressler (1985a, cf. the volumes Hurch Rhodes 1996 and Dziubalska-Kołaczyk 1996), marked corresponds to unnatural. This concept is relative in the sense of "less natural than" (more marked than) and theoretically specified. Within the subtheory of universal markedness, which is a preference theory, marked means universally dispreferred on a given parameter. Within the second subtheory of type adequacy, it means less adequate for a specific language type. And within the third subtheory of language-specific system-adequacy, it means marginal in some respect. For example, unproductive phonological or morphological patterns do not belong to the core of language-specific phonology or morphology (cf. Dressler 1997b). In this contribution we will focus on Natural Morphology (cf. Dressler et al. 1987; Kilani-Schoch 1988) and on Natural Phonology (cf. Dressler 1984; Dziubalska-Kołaczyk 1995, in press) and, within these two fields, on the first and third subtheories.

We understand complexity theory (cf. Bar-Yam 2000, Lemke 1999, Zurek 1990) as a theory of dynamic complex systems, as used for describing complexity and emergence of complexity across all traditional systems of science, from physics through economics to sociology, specifically in a tradition which goes back to Prigogine (1961). Among the various approaches to complexity theory, one consists in distingushing between positive and negative complexity. This distinction may be 
applied, within linguistics, to the wide-spread positive attitude towards regularity and unmarked structures as opposed to a negative attitude towards irregularity and marked structures. A positive attitude is taken in constructivist frameworks which describe the self-organizing emergence of complexity in physical, chemical and biological systems. In this vein, constructivist and emergentist models of language acquisition describe how children construct and reconstruct, step by step, the complexity of their target systems. Put in a nutshell, we assume that children first construct primitive systems of phonetics and cognitive social pragmatics. Only afterwards they construct their first phonological, lexical and syntactic protosystems, and only later their first elementary morphological system ("protomorphology"), as the most intermediate component of all the traditional grammatical components (cf. Dziubalska- Kołaczyk 1997, Bittner et al. 2000).

Such conceptions of complexity theory usually combine with a "building-block" model or a "part-whole" model (cf. Górska 1999) of complex systems. Finally, computational models measure complexity in terms of logical depth, i.e. in the execution time which is necessary for generating the object in question.

How are these building blocks as parts of wholes structured, e.g. in the case of morphology? In their simplest format, they consist of basic and derived elements, such as E. go vs. go-es, go-ing in inflectional morphology or go vs. go-er in derivational morphology. This fundamental relation between unmarked and marked elements is one way in which complexity arises and that constitutes the backbone of even modest morphological richness which all language types possess, with the exception of the ideal isolating language type. We will not focus on the sources of this aspect of markedness, but rather on the following: if an element is marked, it may be more or less marked. Now it would be reasonable to assume that among such alternatives, speakers would opt for the least marked alternative.

So why then should a speaker opt for the second instead of the first of the following choices?

(1) Come in!

(2) Would you be so kind as to come in?

Clearly the second alternative (2) is highly marked in terms of syntactic, morphological, lexical, prosodic and stylistic, expenditure, when compared with the alternative (1). Pragmatics answers the question of choice by referring to politeness, courtesy rituals, face-work, i.e. to sociocultural sources for the rise of such marked politeness strategies. 
Sociocultural accounts are also important in text linguistics. Let us take the semiotic parameter of indexicality. On this parameter of universal markedness theory (cf. Dressler 1996) indexical signantia are preferred which refer anaphorically backwards, over signantia which refer cataphorically forwards to their signata. Thus anaphoric signantia such as the above are preferred over cataphoric signantia such as the below. The reason is that anaphoric relations produce more reliable signs (in the sense of Morris) than cataphoric relations, because it is much easier to identify without equivocation the antecedent of the above than the postcedent of the below.

A glaring counterexample, however, is represented by titles of a text. A title is always cataphoric, it refers forward to the text which is to follow. This highly marked option on the parameter of indexicality has several converging motivations: 1) diachronically, it is the end-result of a long cultural evolution starting in medieval times, when a cataphoric incipit still had an explicit as its anaphoric correspondent. More important, because synchronically valid, are the following motivations: 2) the function of a title is to awake tension and curiosity, which is cataphoric in nature; 3 ) the title need not be a reliable sign, and often it is very unreliable because of the previously mentioned function; 4) many titles, e.g. book titles, originate from an act of name-giving, a special case of Peircean indexicality which must be cataphoric.

Sociocultural changes are a historic source of markedness in other language components as well and may often transcend the task of linguistics. For example, the highly marked typological mix of English morphology goes back, in the long run, to the battle of Hastings.

\section{Markedness of clusters}

In phonology, a good example of a universally marked structure is constituted by consonant clusters. Consonant clusters are rare in the languages of the world (Maddieson 1999). In a sample of 30 representative languages $70 \%$ had no consonant clusters or of a frequency of less than $1 \%$. In every one of these languages at least $85 \%$ of the syllables had simple or zero onsets (Maddieson 1999: 2525). The ground for this is the universal preference for the CV-structure. ${ }^{1}$

There are languages, however, among them also some major world languages with respect to the number of speakers, which do allow for

1 Cf. e.g. Dogil and Braun (1988: 13f), Dziubalska-Kołaczyk (1995: 63ff for a summary of evidence). 
clusters of consonants. Though they differ from language to language, clusters share certain universal traits which either guarantee their survival in a language or let them be similarly treated, cross-linguistically, by children, aphasics, learners of foreign languages or every-day casual talkers. Those universal traits are expressible in terms of phonotactic preferences which derive the preferred clusters for all positions. Their function is, on the one hand, to counteract the $C V$-only preference and, on the other, to counteract the creation of dysfunctional clusters. Most typically across phonological models, such conditions on clusters are expressed in terms of phonotactic constraints.

What all this suggests is that, once a language does have clusters, not all of them are equally marked. What is relevant for the present discussion is, (a) how the relatively more marked clusters arise in languages, and, (b) how to measure the relative markedness of clusters. One occasion when we can observe the rise of marked clusters is in phonostylistic variation. Before we inspect some cases of this, we need the aforementioned measure of markedness.

\subsection{Universal phonotactics}

Phonotactic preferences in the Beats-and-Binding phonology (Dziubalska-Kołaczyk 2001) specify, for a given position in a word, the hierarchy of clusters, i.e. they divide a potential cluster space into the preferred clusters, the dispreferred clusters (which are possible, though functionally less adequate in the given position) and the impossible clusters. $^{2}$

The Optimal Sonority Distance Principle (OSDP) defines the way in which segments should order themselves in a successful sequence: the relations between sonority distances between pairs of neighbouring phonemes should be optimally balanced.

They refer to the sonority values of the scale below: ${ }^{3}$

The sonority hierarchy:

vowels semivowels liquids nasals fricatives affricates plosives

0

1

2

3

4

5

6

2 The dispreferred clusters are all potentially existent. They are dispreferred due to their misplacement within a word. The impossible clusters are excluded on logical grounds by the well-formedness conditions.

3 Cf. Dziubalska-Kołaczyk (1995: 87 and other places) for discussion of the notion of sonority. 
e.g.

$l a=$ distance of two positions $=2, s w=$ distance of three positions $=3$, $k a=$ distance of six positions $=6$, etc.; so, e.g. $k a>s w>l a$

For instance, the preferred double initials are defined by the following condition:

\section{$C_{1} C_{2} V: \quad \mid \operatorname{son}\left(C_{1}\right)$ son $\left(C_{2}\right)|\geq| \operatorname{son}\left(C_{2}\right)$ son $(V) \mid$}

\section{i.e.: sondis $\left(C_{1}, C_{2}\right) \geq$ sondis $\left(C_{2}, V\right)$}

The condition reads:

In word-initial double clusters, the sonority distance (sondis) between the two consonants should be greater than or equal to the sonority distance between a vowel and a consonant neighbouring on it.

Sonority distances between segments as specified by the phonotactic preference conditions show a regular distribution when plotted on a two-dimensional diagram. Below a diagram representing preferred double initials is shown.

sondis $\left(\mathrm{C}_{1}, \mathrm{C}_{2}\right)$

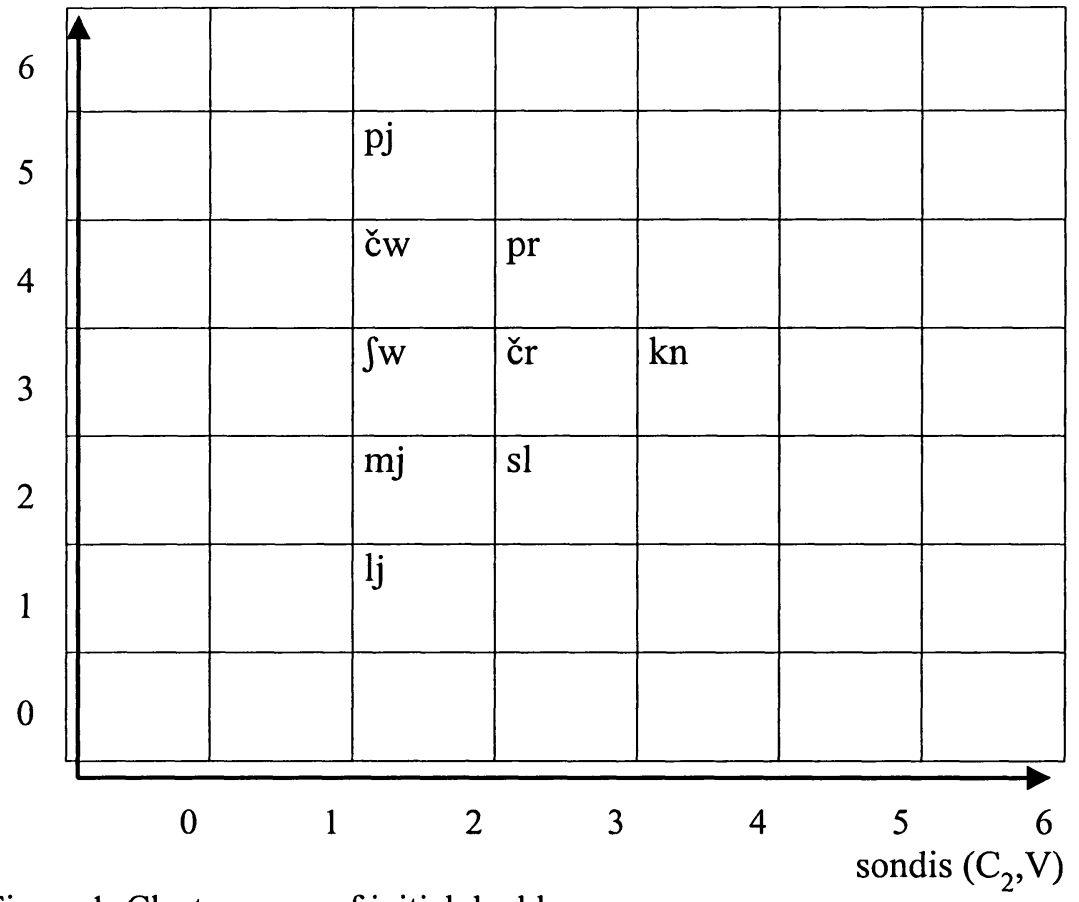

Figure 1. Cluster space of initial doubles. 
There is neither space nor reason to present the whole model of the Beats-and-Binding phonotactics here (cf. Dziubalska-Kołaczyk 2001, in press). Still, the model will be used when evaluating the degree of markedness of clusters arising in phonostylistics and in diachrony.

\subsection{Rise of marked clusters in phonostylistics}

Casual style is a potential source of marked clusters. The application of casual speech processes, i.e. mainly speaker-friendly lenitions (especially massive vowel reductions), may lead to a temporary rise of "new" clusters which are marked with reference to the universal phonotactics. Some of them may potentially get socioculturally reinforced and become part of language-specific phonotactics.

In the examined data (cf. Madelska 1987), out of 3106 lexical word types, in the production of 27 types marked clusters were found, all but three word-initial. They arose via vowel reduction.

Table 1. "New" clusters resulting from vowel reduction

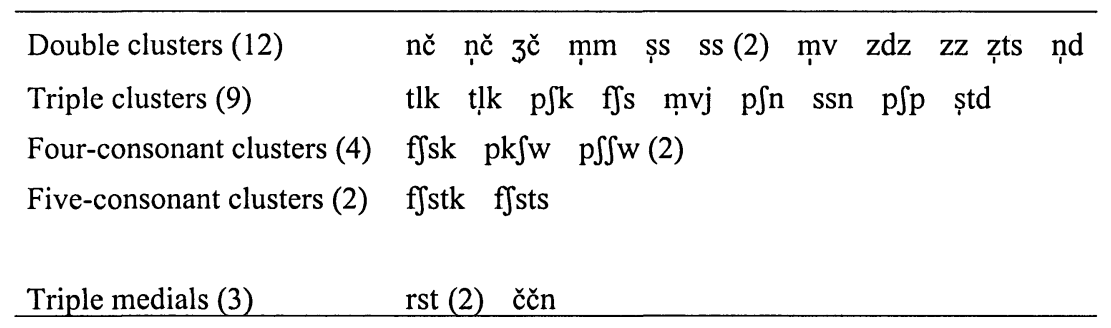

Table 2. Examples of words with "new" clusters

\begin{tabular}{|c|c|c|c|c|}
\hline $\begin{array}{l}\text { Rank no. } \\
\text { (text freq.) }\end{array}$ & $\begin{array}{l}\text { word type in } \\
\text { spelling }\end{array}$ & & $\begin{array}{l}\text { lexical form } \\
\text { transcription }\end{array}$ & $\begin{array}{l}\text { token phonostylistic } \\
\text { transcription }\end{array}$ \\
\hline 30. & znaczy & $\mathrm{C}$ & znači & nči niči \\
\hline 35. & tylko & $\mathrm{C}$ & tilks & tlko tlko \\
\hline 61. & wszystko & $\mathrm{C}$ & fJistko & fJskı fJstkっ \\
\hline 84. & przykład & $\mathrm{C}$ & pSikwat & pSkat p $\int k w a t$ \\
\hline 118. & wszyscy & $\mathrm{C}$ & f $\int i s t s i$ & $\mathrm{f} \int \mathrm{si} \quad \mathrm{f} \int \mathrm{stsi}$ \\
\hline 188. & rzeczywiście & $\mathrm{C}$ & $3 \varepsilon$ čivict & उči- \\
\hline 204. & mimo & $\mathrm{C}$ & $\operatorname{mim}$ & $\mathrm{mmo}_{1}$ \\
\hline 271. & mówię & $\mathrm{C}$ & muvj $\tilde{\varepsilon}$ & $\operatorname{mvj\varepsilon }$ \\
\hline 360. & swoim & $\mathrm{C}, \mathrm{H}$ & sfojim & șsoim \\
\hline 464. & przynajmniej & $\mathrm{C}$ & pSinajmpej & p $\int \mathrm{na-}$ \\
\hline
\end{tabular}


Summing up, all "new" initial clusters produced in the corpus were universally marked. Thus, phonostylistic variation of casual speech shows as a potential source of marked clusters.

Another process standing out in the inspected corpus of Polish casual speech is that of smoothing of an intervocalic consonant which produces a vowel hiatus with the first vowel stressed. The transition between the two vowels remains rather smooth (slightly gliding), still the weakening or deletion of an intervocalic consonant leads to the distortion of a CVCV structure, and as such produces a marked effect (with respect to the CV preference). In the corpus of 3106 word types, 177 underwent the process and thus demonstrated the hiatus.

Table 3. Examples of "new" hiatuses (first ten cases)

\begin{tabular}{cll}
\hline Rank no. (text freq.) & word type in spelling & \\
\hline 46. & teraz & $\mathrm{H}$ \\
55. & potem & $\mathrm{H}$ \\
69. & miałam & $\mathrm{H}$ \\
77. & dużo & $\mathrm{H}$ \\
79. & domu & $\mathrm{H}$ \\
106. & takiego & $\mathrm{H}$ \\
110. & człowiek & $\mathrm{H}$ \\
142. & trzeba & $\mathrm{H}$ \\
144. & wydaje & $\mathrm{H}$ \\
153. & mama & $\mathrm{H}$ \\
\hline
\end{tabular}

\subsection{Converging (?) evidence from diachrony}

Casual speech vowel reductions leading to the formation of new clusters or at least to the rise of syllabic consonants as observed in the Polish data remind one of the diachronic emergence of syllabic liquids $/ \mathrm{rl} / \mathrm{in}$ some other Slavic languages (Czech, Slovak, Serbo-Croatian, Slovene; cf. e.g. Czech and Slovak prst 'finger', vlk 'wolf'). Thus, their potential source could be a similar casual speech process, producing marked structures in terms of the $\mathrm{CV}$ preference and the general figure-and-ground principle. In other words, the resulting structures are functionally much less effective for the listener; however, they result from the speaker-friendly preference for ease of articulation. In casual speech the speaker is the winner, and therefore a conflict between speaker-friendly and listenerfriendly preferences is resolved to the benefit of the speaker, even if the arising structure is marked. 
Another diachronic example of a weak vowel reduction was the disappearance of weak yers in the early history of Polish (still in the pre-written period). As a result, consonant clusters came into being, e.g. tba, psa, sjem (later sejm), bochnek (later bochenek), szmer, toktek (later Łokietek), $\mathrm{msza}^{4}$ (cf. Walczak 1999: 37ff). All the word-initial clusters mentioned here are marked initials (with reference to the universal phonotactic preferences); the medial ones are good medials. A casual speech vowel reduction in the discussed corpus also produced marked initials and unmarked medials. In the time of the above changes, Polish had free movable stress, i.e. typologically it could be classified as a stress-timed language. ${ }^{5}$ Vowel reductions are typical of stress-timed languages, triggered especially by the casual style and fed into the formal style. Consonant clusters are a predictable outcome; since they are not aims in themselves, but a side-effect of another process, they are predictably relatively marked.

Vowel contraction in sequences with an intervocalic $/ \mathrm{j} /$ may serve as an example confirming such a simplification tendency, typical of casual speech. The forms $/ \mathrm{VjV} /$ changed from Proto-Slavic via Slavic to Polish as in the following example: ${ }^{*}$ mlod/aja/ $\rightarrow \mathrm{młod} / \bar{a} / \rightarrow m \nmid o d / a /$. Therefore, in Polish, graje $\rightarrow$ gra, umieje $\rightarrow$ umie, rozumieje $\rightarrow$ rozumie.

The last example shows a case of univerbation as part of grammaticalization in Polish whereby an arising marked cluster was repaired already in an intermediate form: byt jeśm $\rightarrow$ byteśm $\rightarrow$ bytem.

\section{Markedness in morphology}

For the rise of markedness in morphology we bring evidence from verb inflection in Standard Italian and in Italo-Romance dialects. Following Dressler - Thornton (1991), we assume that all Italian verbs should be arranged into two macroclasses. The first macroclass ${ }^{6}$ (infinitive type amare 'to love') is the really productive and homogeneous one and represents the default, unmarked macroclass. The second macroclass (infinitive type temere 'to fear', credere 'to believe', finire 'to finish') is not homogeneous and constitutes the marked macroclass. Here marked-

4 Some of those clusters later on (in Old Polish) underwent simplification, e.g. czsokoli $\rightarrow$ cokoli (cf. Walczak 1999: 85).

5 In Old Polish stress shifted to the initial vowel of a word, while at the turn of Old and Middle Polish - to the penultimate position (cf. Walczak 1999: 79ff).

6 With the exception of the isolated paradigms dare 'to give', stare 'to stay', andare 'to go', fare 'to do'. 
ness refers to the third subtheory of language-specific system adequacy, as pioneered for morphology by Wurzel (1984). A macroclass is hierarchically built up from microclasses according to a building-block model of complexity theory.

The first case we are going to present is the expansion of the present indicative and subjunctive $1^{\text {st }}$ plural marker -iamo in Standard Italian. This suffix replaced the earlier and etymologically expected markers -amo, -emo, -imo, such as in, e.g. am-a-mo, cred-e-mo, fin-i-mo, still present in some Italian dialects.

The source of the suffix -iamo is Latin -eamus or -iamus, that is, the Present Subjunctive $1^{\text {st }}$ plural ending of verbs like timere 'to fear', credere 'to believe', finire 'to finish'.

Table 4. Italian $1^{\text {st }}$ plural present

\begin{tabular}{|l|c|c|c|c|}
\cline { 2 - 5 } \multicolumn{1}{c|}{} & $\mathbf{1}^{\text {st }}$ macroclass & \multicolumn{3}{c|}{$2^{\text {nd }}$ macroclass } \\
\hline & amare 'to love' & temere 'to fear' & credere 'to believe' & finire 'to finish' \\
\hline Latin Indicative & $\begin{array}{c}\text { amamus } \\
\text { Latin Subjunctive }\end{array}$ & $\begin{array}{c}\text { timemus } \\
\text { amemus }\end{array}$ & $\begin{array}{c}\text { credimus } \\
\text { credamus }\end{array}$ & $\begin{array}{c}\text { finimus } \\
\text { finiamus }\end{array}$ \\
\hline Old. It. Ind. & amamo & tememo & credemo & finimo \\
Old. It. Subj. & amemo & temiamo & crediamo & finiamo \\
\hline $\mathbf{1 3}^{\text {th }}$ C Flor. Ind. & amiamo & tememo & credemo & finimo \\
$\mathbf{1 3}^{\text {th }}$ C Flor. Subj. & amiamo & temiamo & crediamo & finiamo \\
\hline Mod. St. It. Ind. & amiamo & temiamo & crediamo & finiamo \\
Mod. St. It. Subj. & amiamo & temiamo & crediamo & finiamo \\
\hline
\end{tabular}

Three successive stages of the spread of the suffix -iamo can be differentiated (see Table 4):

Stage 1: Old Florentine texts (approximately $12^{\text {th }}-13^{\text {th }}$ C) attest the expansion of the $2^{\text {nd }}$ macroclass present subjunctive $1^{\text {st }}$ and $2^{\text {nd }}$ plural endings -iamo, -iate to the $1^{\text {st }}$ macroclass present subjunctive, as in, e.g. temiamo, dormiamo and amiamo (cf. Castellani 1952). Note that the etymological first macroclass present subjunctive $1^{\text {st }}$ plural amemo looked like the second macroclass indicative $1^{\text {st }}$ plural tememo; hence a distinction between indicative and subjunctive was called for. Thus -iamo became a superstable marker, that is, a marker that holds for all verb classes in the subjunctive. This generalization represents an optimization on the universal naturalness parameter of biuniqueness. The differentiation of $1^{\text {st }}$ plurals according to the thematic vowels still holds in the unmarked indicative, though. Thus we have in the indicative amamo "we 
love", tememo "we fear", finimo "we finish". The neutralization in the marked category subjunctive finds a parallel in the neutralization of all three persons in the singular.

Note that any homophony between indicative and subjunctive is avoided in all other persons, e.g. in Standard Italian pres. ind. $1^{\text {st }} \mathrm{sg}$. amo, credo, $2^{\text {nd }} \mathrm{sg}$ am-/cred-i, $3^{\text {rd }}$ sg. ama, crede vs. pres. subj. $1^{\text {st }} 3^{\text {rd }} \mathrm{sg}$. am-i, cred-a; pres. ind. $2^{\text {nd }} \mathrm{pl}$. amate, credete vs. pres. subj. $2^{\text {nd }} \mathrm{pl}$. am-l cred-iate, pres. ind. $3^{\text {rd }} \mathrm{pl}$. amano, credono vs. pres. subj. $3^{\text {rd }} \mathrm{pl}$. amino, credano.

Stage 2: The $1^{\text {st }}$ plural ending -iamo spread to the present indicative of the first macroclass verbs, e.g. amiamo vs. tememo and finimo. ${ }^{7}$ This extension seems to contradict biuniqueness and the tendency to replace marked with unmarked forms, for -iamo extended from a marked category of the marked second macroclass to an unmarked category of the unmarked first macroclass. However, the Latin subjunctive functioned both as subjunctive and as hortative in the $1^{\text {st }}$ plural. Thus, we can explain the expansion of -iamo from the marked subjunctive into the unmarked indicative as a case of markedness reversal in early child speech. Often the first occurrences of $1^{\text {st }}$ plurals appear as hortative in early child speech (cf. Makovec-Černe - Dressler 1997). Thus we can assume that the subjunctive $1^{\text {st }}$ plural with hortative function was acquired and used before the indicative $1^{\text {st }}$ plural and that the dominant hortative form was extended to all occurrences of $1^{\text {st }}$ plural.

Stage 3: The indicative ending -iamo expanded from the productive first macroclass to the unproductive second macroclass. ${ }^{8}$ Thus, it became a superstable marker both in the indicative and in the subjunctive. Such a process both corresponds to and contrasts with the universal naturalness parameter of biuniqueness: on the one hand there is just one marker of $1^{\text {st }}$ plural in the present tense (without class or mood differentiation; for the

7 Early Italian texts attest the following pairs in $13^{\text {th }}$ century Italian: pres. ind. $1^{\text {st }} \mathrm{pl}$. dicemo 'we say', difendemo 'we defend', attendemo 'we wait for' vs. pres. subj. $1^{\text {st }}$ pl. diciamo, difendiamo, attendiamo (cf. Alinei 1968).

8 Note that in the pres. ind. of the second macroclass the ending -iamo has been used for a long time together with the endings -emo and -imo in free variation, as attested in Old Florentine texts, such as the $14^{\text {th }}$ century Lettere e istruzione della prima metà del secolo XIV dettate dai Cancellieri [di Firenze] in lingua volgare (1350), where the pres. Ind. $1^{\text {st }}$ plurals vedemo, ricevemo 'we see, receive' (inf. vedere, ricevere) and rispondiamo 'we answer' (inf. rispondere) are in the same paragraph! Many Old Florentine texts attest that the $1^{\text {st }}$ plurals in -iamo, -emo, -imo cohabited in free variation up to the $16^{\text {th }}$ century. 
other tenses cf. superstable Fut. -(re)mo, Impf. -(va)mo, Passato Remoto $-(V) m m o)$, on the other hand the distinction of indicative and subjunctive in the $1^{\text {st }}$ plural is neutralised. This is a unique phenomenon in Standard Italian verb inflection.

Dialectal data support our analysis:

- In Southern and Central Ligurian, Western Lombard, Old Veneto, Sicilian Gallo-Italian and in the Latium dialects of Velletri, Nemi and Cervara, we find the superstable ending -emo in the indicative (cf. Forner 1997, Savoia 1997, Lurati 1988, Rohlfs 1968). These dialects have lost the subjunctive. Since in no dialect the indicative $1^{\text {st }}$ plural -emo of temere, credere has expanded at the expense of -amo and -imo, the source of the superstable $1^{\text {st }}$ plural indicative -emo must be the old hortative of the $1^{\text {st }}$ macroclass (type amare, indicative amamo, subjunctive amemo). This supports our analysis of the expansion of -iamo to the indicative of the first macroclass in stage 2 and of its further extension to the second macroclass in stage 3.

- In Southern Latium and Bolognese dialects we find the superstable $1^{\text {st }}$ plural marker -amo in the indicative (in the precise forms -amo and -am, [an], respectively; cf. Foresti 1988, Hajek 1997, Rohlfs 1968, Jaberg - Jud 1928-1940). The expansion of -amo from the first macroclass to the second macroclass supports our analysis of the spread of -iamo from the first productive macroclass to the second macroclass in stage 3 .

The extension of -iamo is a part of a general typological shift from the strong inflecting language Latin to the weak inflecting language Italian: the increase of superstable markers brings about a decrease of class differentiation.

We assume (cf. Dressler 1997) that the unmarked core of morphology consists in its productive patterns, i.e. productive categories, rules and classes. Therefore the first macroclass type amare may be regarded as the unmarked core of both Latin and Italian verb inflection (cf. Dressler 1999). This notion of Natural Morphology, at first sight, can be reconciled with the psycholinguistic dual mechanism model. According to this model (cf. Clahsen et al. 1992, Clahsen 1999, Pinker - Prince 1994), Italian verbs are arranged into "regular" verbs, i.e. the default, productive first macroclass, and "irregular" ones, i.e. the non-default, unproductive second macroclass, whereas the so called regular verbs are handled by rules, so called irregular verbs are simply stored in the mental lexicon as such and not subject to rules, that is, all inflectional forms of 
amare are generated by rules, all inflectional forms of temere, credere, finire are stored and accessed via lexical look-up.

One diachronic process which operates on stored morphological forms is surface analogy (cf. Motsch 1981). Therefore, surface analogy phenomena are claimed to be possible only for stored morphology, i.e., only in the second macroclass of Italian verbs and of their Latin antecedents. However, some noteworthy phenomena exist in ItaloRomance dialects that cast doubt on this dual mechanism model of the Italian mental lexicon.

For example, the dual mechanism account for Italian verb inflection is challenged by the expansion of absolute past markers -edi and -etti in Italo-Romance dialects (cf. Väänänen 1982, Vineis 1974, Rohlfs 1968, Pasquarelli Clivio 1994, Magni 1997)

Latin Perfect forms such as 1. sg. amavi (from amare), finivi (from finire) yielded the Italian "weak" absolute past forms amai 'I loved', finii 'I finished'. In contrast, the irregular Latin verb dare, $1^{\text {st }}$ singular indicative present $d o$, perfect dedi yielded Italian dare 'to give', indicative present $d o$ and Standard Italian absolute past diedi, archaic and dialectal dedi. Now, in various Italo-Romance dialects this pattern was analogically extended from diedi/dedi and even a suffix -iedi/-edi was extracted. Again, we can differentiate three or even four successive stages

Stage 1: In the first stage, diedi was extended to compounds and prefixations of dare (which had a different perfect in Classical Latin) and even to non-cognate, phonologically similar verbs with root-final / $d /$. Note that already since the $1^{\text {st }}$ century BC, and then particularly in Vulgar Latin, perfect forms are attested, such as, descendidit 'went down' (Q. Valerius Antias $1^{\text {st }}$ century $\mathrm{BC}$, according to Gellius, $\left.6,9,17\right)$, reddedit 'gave back' (CIL V 6464), perdedi (CIL III 8847), prendiderunt 'they took' (Itala, Joh. 21, 3), adcendederunt 'they ignited' (Act. Arv., 240 A.C.), respondidi (Caper, Gramm. VII, 103, 7). ${ }^{9}$ Italian dialectal attestations are: Old Italian, ${ }^{10}$ Modern Tuscan, Umbrian and Northern Laziale rendiede 'gave back' (vs. Standard Italian rese, infinitive rendere), vendiedi and vendedi 'I sold'

9 Further attestations are: edidit 'ate' (CIL III 13608), impendidit 'spent' (CIL VIII 21538), prandiderunt 'they lunched' (Itala, Joh. 21, 15; cf. prandidi in Appendix Probi, IV, 184, 18-21 (6 $6^{\text {th }} \mathrm{C}$ BC) and prandiderint in Peregrinatio Aetheriae, 27, 9 $\left.\left(4^{\text {th }} \mathrm{C} \mathrm{BC}\right)\right)$, cf. Väänänen (1982: 247).

10 The absolute past $1^{\text {st }}$ singular form rendiedi 'I gave back' is attested in $14^{\text {th }}$ century Tuscan (cf. Negroni 1885). 
(vs. Standard Italian vend-e(tt)i, infinitive vendere), rispondiedi 'I answered' (vs. Standard Italian risposi, infinitive rispondere).

Table 5. Extension of -edi: First Stage

\begin{tabular}{|c|c|c|c|}
\hline & Classical Latin & Late Latin & Ital. dialects \\
\hline $\begin{array}{l}\text { Lat. reddere, pr. ind. 1. sg. reddo > } \\
\text { It. rendere, pr. ind. rendo }\end{array}$ & $\begin{array}{l}\text { reddidit } \\
\text { 'gave back' }\end{array}$ & reddedit & rendiede \\
\hline $\begin{array}{l}\text { Lat. vendere, pr. ind. } 1 . \text { sg. vendo }> \\
\text { It. vendere, pr. ind. vendo }\end{array}$ & $\begin{array}{l}\text { vendidi } \\
\text { 'I sold' }\end{array}$ & vendedi & vendiedi \\
\hline $\begin{array}{l}\text { Lat. perdere, pr. ind. 1. sg. perdo > } \\
\text { It. perdere, pr. ind. perdo }\end{array}$ & $\begin{array}{l}\text { perdidi } \\
\text { 'I lost' }\end{array}$ & perdedi & perdiedi \\
\hline $\begin{array}{l}\text { Lat. prehendere, pr. ind. } 1 . \mathrm{sg} . \\
\text { prehendo }>\text { It. prendere, pr. ind. } \\
\text { prendo }\end{array}$ & $\begin{array}{l}\text { prehendi } \\
\text { 'I took' }\end{array}$ & $\begin{array}{l}\text { prendidi/ } \\
\text { prendedi }\end{array}$ & prendiedi \\
\hline $\begin{array}{l}\text { Lat. respondere, pr. ind. } 1 . \mathrm{Sg} . \\
\text { respondeo > It. rispondere, pr. ind. } \\
\text { rispondo }\end{array}$ & $\begin{array}{l}\text { respondi } \\
\text { 'I answered' }\end{array}$ & $\begin{array}{l}\text { respondidi/ } \\
\text { respondedi }\end{array}$ & rispondiedi \\
\hline $\begin{array}{l}\text { Lat. adcendere, pr. ind. } 1 . \mathrm{Sg} \text {. } \\
\text { adcendo > It. accendere, pr. ind. } \\
\text { accendo }\end{array}$ & $\begin{array}{l}\text { adcenderunt } \\
\text { 'they ignited' }\end{array}$ & adcendederunt & accendiedero \\
\hline
\end{tabular}

Stage 2: The second stage of expansion concerned other $2^{\text {nd }}$ macroclass verbs with roots ending in unvoiced dental, e.g. Pisano, Pistoiese, Elbano mettiede 'he/she put', battiedi 'I beat PAST', potiedi 'I was able', partiede 'he/she left', sentiedi 'I heard' (infinitives mett-ere, batt-ere, pot-ere, part-ire, sent-ire; cf. Jaberg - Jud 1928-1940, Rohlfs 1968, Giannelli 1976). This is a phonologically based extension from voiced dental to all dental stops. Such a phase is anticipated in Late Latin texts as well, e.g. perfect subjunctive battederit (Lex Salica 35, 4 cod. 5).

Stage 3: In the third stage, the suffix -iedi/-edi expanded to the verb stare, yielding the Tuscan and Umbrian absolute past form stiedi.

The Italian rhyme-verbs dare 'to give' and stare 'to stay' form a 'short verb family'. According to our model of stored morphology in Pöchtrager et alii (1998), "a family of paradigms is a looser group of paradigms than any type of (paradigm) class". With the term paradigm family we refer to the Wittgensteinian notion of family resemblances and to surface morphological generalizations such as rhymes and other phonologically based similarities.

All the above described processes are compatible with the dual mechanism account of Italo-Romance verb inflection, because they affect 
the unproductive second macroclass or unproductive isolated paradigms of the first macroclass.

Stage 4: Yet, in some Corsican dialects we find a fourth stage: here -edi expanded through surface analogy to the productive first macroclass verbs as well (cf. Rohlfs 1968, Melillo 1977), as in, e.g. inf. purtà, absolute past purtèdi 'I brought' (vs. Standard Italian portare, portai), inf. vultà, absolute past vultèdunu 'they turned' (vs. Standard Italian voltare, voltarono), inf. marità, absolute past si maritède 'he/she got married' (vs. Standard Italian maritarsi), inf. calà, absolute past calèdunu 'they let down' (vs. Standard Italian calare, calarono), inf. cumprà, absolute past cumprèdi 'I bought' (vs. Standard Italian comprare, comprai), inf. chiamà, absolute past chiamède 'he/she called' (vs. Standard Italian chiamare, chiamo).

The generalization of -edi introduced a marked stored element into the productive and homogeneous first macroclass absolute past, and even neutralized the class distinctions via the thematic vowels /-a-/ vs. /-e-/. However, such a process is natural on the universal parameter of biuniqueness by following the system-independent naturalness preference for uniformity of exponence. Moreover this change introduced a more salient perfect ending.

Whereas this analogical extension challenges the generative dual mechanism model of Pinker (1994), Clahsen (1999) and their research associates, it is compatible with the psycholinguistic competition and race models of Frauenfelder - Schreuder (1992). Such models have been also used within Natural Morphology (cf. Dressler et al. 2001). According to such models, there is an overlap of, and a competition between, rule mechanism and storage. On the one hand, frequently used forms of productive patterns are also stored: thus, the perfect pattern $d / s t i e d i$ extended to dental-final roots of the first macroclass, e.g. purt-à. On the other hand, speakers may extract abstract rule patterns from frequent and homogeneous stored patterns. Thus, speakers of Corsican extracted a suffix -edi/-e from verbs with dental final roots and used it productively even within the first productive macroclass.

A parallel to the -edil-iedi generalization is represented by the extension of the rival pattern -etti. The Proto-Romance perfect form ${ }^{*}$ stetwi (from the verb stare, ind. pres. $1^{\text {st }}$ sg. sto) yielded Italo-Romance stetti, a pattern that was extended as well (cf. Magni 1997, Rohlfs 1968, Pasquarelli Clivio 1994). 
Stage 1: In a first stage, the pattern extended to the phonologically most similar rhyme-word dare (short verb, dental onset), thus yielding the Italian absolute past by-form detti;

Stage 2: In a second stage, it extended to second-macroclass verbs ending in dental, such as credetti 'I believed' (inf. credere), perdetti 'I lost' (absolute past by-form persi, inf. perdere), Old Italian and dialectal rendetti (vs. Standard Italian resi, inf. rendere), and so on;

Stage 3: In a third, still later stage, -etti expanded to other second macroclass verbs whose root did not end in dental, both in Standard Italian and, even more widely, in many Italian dialects (cf. Radtke 1988, Rohlfs 1968, Foresti 1988, Pasquarelli Clivio 1994), e.g. Standard Italian and dialectal ricevetti 'I received' (inf. ricevere), Old Italian and dialectal tacetti 'I was silent' and tenetti 'I kept' (respectively vs. Standard Italian tacqui, inf. tacere and tenni, inf. Tenere);

Stage 4: In a fourth, still later stage, -etti spread to the dental-final root of the suppletive paradigm and-are 'to go', as in, e.g. Tuscan andetti, Umbrian and Northern Laziale annètte (vs. Standard Italian $1^{\text {st }} \mathrm{sg}$. andai, $3^{\text {rd }}$ sg. andò; cf. Jaberg-Jud 1928-1940, Giannelli 1976, Rohlfs 1968).

Again, all the above quoted data and processes still fit to the dual mechanism account of Italo-Romance verb inflection.

Stage 5: However, when we look at other dialect data (cf. Giammarco 1979, Marinucci 1988, Rohlfs 1968, Jaberg-Jud 1928-1940, Pasquarelli Clivio 1994, Foresti 1988), we find that the spread of the Absolute Past form -etti involved the first macroclass as well, as in e.g. Old Umbrian (Cassio da Narni, 16 ${ }^{\text {th }} \mathrm{C}$ ) guardètte 'he watched', inf. guardà (vs. Standard Italian guardò, guardare), or Modern Umbrian (Todi) magnètte 'he/she ate', inf. magnà (vs. Standard Italian mangiò, mangiare), lavétti 'I washed', inf. lavà (vs. Standard Italian lavai, lavare), or Modern Western Abruzzese fermétta 'I/he stopped', inf. fermà (vs. Standard Italian fermai Ifermò, fermare), parlétto 'I/ he talked', inf. parlà (vs. Standard Italian parlailparlo, parlare), truvétta ' $\mathrm{I} / \mathrm{he}$ found', inf. truvà (vs. Standard Italian trovai/trovò, trovare), cumbrétto 'I/he bought', infinitive cumbrà (vs. Standard Italian comprai/comprò, comprare), or in Northern Laziale (Grotte di Castro) cerchétti 'I looked for', infinitive cercà (vs. Standard Italian cercai, cercare), diventètte 'he became', infinitive diventà (vs. Standard Italian divento, diventare), Marchigiano (Petritoli and Monterubbiano) pensétti 'I thought', infinitive pensà (vs. Standard Italian pensai, pensare), cominciétte 'he began', infinitive comincià (vs. Standard Italian cominciò, cominciare). 
Thus, here again, we find first surface analogical extensions and then productive rule extraction.

Our analysis of the expansion of -edi and -etti are further supported by those dialects where -edi and -etti endings coexist in free variation (in the following we abstract from the precise phonological realisation of the types -iedi and -etti). We find free variation between

diedi detti (inf. dare, ind. pr. $1^{\text {st }}$ sg. do) detti (inf. dare, ind. pr. $1^{\text {st }}$ sg. Do)

stiedi $\quad$ stetti (inf. stare, ind. pr. $1^{\text {st }}$ sg. Sto)

andiedi andetti (inf. andare, ind. pr. $1^{\text {st }} \mathrm{sg}$. vo)

in Tuscan, Umbrian and Northern Latium dialects of Arezzo, Firenze, Pisa, Lucca, Pistoia, Stia, Greve in Chianti, Barberino del Mugello, Elba, Acquapendente, Perugia, Marsciano, Castagneto Carducci, Chiusdino, Gavorrano, Sinalunga, Montefollonico, Tarquinia (cf. Giannelli 1976, 1988, Jaberg-Jud 1928-1940, Rohlfs 1968). The variant andiedi is missing in the dialects of Chiavaretto, Montefiascone and Cerveteri. Up to the $19^{\text {th }}$ century the dialect of Lucca had all the three variable pairs plus the -etti forms (cf. Pieri 1890-1892):

fetti (inf. fare 'to do', ind. pr. $1^{\text {st }} \mathrm{sg}$. Fo)

etti (inf. avere 'to have', ind. pr. $1^{\text {st }} \mathrm{sg}$. ho)

The Tuscan dialect of Santa Fiora (Amiata Mount) has all the three variable pairs in -etti plus the following ones (cf. Rohlfs 1968):

fetti (inf. fare 'to do', ind. pr. $1^{\text {st }} \mathrm{sg}$. Fo)

etti (inf. avere 'to have', ind. pr. $1^{\text {st }} \mathrm{sg}$. $\mathrm{Ho}$ )

setti (inf. essere 'to be', ind. pr. $1^{\text {st }} \mathrm{sg}$. so)

These distributions confirm both the relevance of the paradigm family of rhyming short verbs, (cf. the above mentioned third stage of -edi expansion and of the first and fourth stage of the -etti extension) and the limitation of -iedi to dental final verb roots (with the much later exception of Corsican).

4. Morphological vs. phonological markedness

In the previous examples we have had cases of markedness conflicts between various parameters of universal naturalness within the same component or module. We have discussed phenomena which are unmarked on one parameter, but marked on others, either within phonology or morphology. Much more work has been done on markedness conflicts be- 
tween parameters of different components, especially between phonology and morphology (e.g. Dressler 1985, Wurzel 1980, Singh 1994). Thus we do not want to go into the often treated diachronic mechanisms of morphologisation of phonological rules, conflicts which introduce marked phonological and morphonological phenomena to the benefit of an unmarked solution on some morphological parameter.

Instead we want to briefly discuss examples from our respective languages, where the universal morphological parameter of morphotactic transparency interacts with universal phonological parameters.

The first example comes from Austrian and Swiss German dialects where the definite plural and feminine singular article die has undergone a phonological shortening to $d^{\prime}$ (cf. Dressler 1984b, Suter 1992): this represents a natural phonological weakening process (lenition) which tends to be maximised in unstressed function words. This process, however, results within the phonological word of a definite noun phrase in difficult marked consonant clusters. As a phonological repair strategy (as some phonologists, such as Singh 1987, would say), further natural phonological processes of fusion reduce phonological markedness. Table 6 gives a simplified overview, where the nouns are given in its Standard German shape:

Table 6. Effects of G. die > dialectal $d^{\prime}$ 'the' (Pl./fem.Sg.)

\begin{tabular}{|c|c|c|}
\hline d' Sau & [ts]au & 'the sow' \\
\hline d' Frau & [pf]rau & 'the woman' \\
\hline d' Blume(-n) & [b:]lume $(-n)$ & 'the flower(-s)' \\
\hline d' Männ-er & [m:]änn-er & 'the men' \\
\hline
\end{tabular}

Although the affricates [ts] and particularly [pf] and word-initial geminate consonants are phonologically marked phenomena, they are less marked phonologically than the input clusters to the left of the table. But this decrease of phonological markedness is outweighed by an increase in morphological opacity, i.e. a greater difficulty to identify the definite article and the word-onset of the noun. This means introduction of markedness on the morphological parameter of morphotactic transparency.

The second set of examples for a markedness conflict between phonology and morphology comes from Italian. Due to a natural phonological rule, the final vowel $-a$ of the feminine definite article $l a$ is deleted before nouns with vocalic word-onset in Standard Italian, e.g. la/ una amica > l'/un'amica 'the/a friend FEM' (cf. Dardano - Trifone 1985, 
Serianni 1991). Yet this phonological rule is sometimes infringed in contemporary written Italian, notably in journalistic usage (Vanvolsem 1983, Mengaldo 1994, Dardano - Trifone 1985, Nencioni 1997). Here morphotactically transparent alternatives are preferred, such as la amica, la urgenza 'the urgency FEM' (Serianni 1989: 163), la ossificazione 'the ossification' (Stuart 1984: 133), la Ale 'the Alexandra' (cf. Coveri et al. 1998: 205). In the last example, the feminine gender of the proper name Ale is transparently expressed via the full article $l a$, as the clipped form Ale can refer both to a feminine proper name, i.e. Alessandra, and to a masculine one, i.e. Alessandro (thus l'Ale is a clipping of masculine l'Alessandro only). In such examples the morphological principle of morphotactic transparency prevails over phonological naturalness, thus yielding outputs that are phonologically marked but morphologically unmarked.

Inhibition of the phonological vowel deletion rule is much more frequent with the indefinite article una than with the definite article $l a$, e.g. una ipotesi 'a hypothesis FEM', una amnistia 'an amnesty FEM', una ustione 'a burn FEM', una immagine 'an image FEM' (Stuart 1984: 133).

This may be due to the greater salience of uno, una (with at least secondary stress on the first syllable). According to the "rich get richer principle" (cf. Dressler 1984a) the already more salient character of una gets reinforced by more morphotactic transparency within the noun phrase.

Note that morphotactic transparency is not restored in the masculine definite article, e.g. l'amico (*lo amico) 'the friend MASC', l'osso 'the bone MASC', l'istituto 'the institute MASC', l'uncino 'the hook MASC'. What may be responsible for this difference? The full form of the masculine definite article is either $i l$ (default) or $l o$, which is used only before nouns with word-onset in $z, x, p n, p s, g n, s c, s b, s l, s t, s g, s f$. Therefore, the definite article with vowel deletion l' marks only the masculine nouns beginning with a vowel in written Italian. The restitution of transparency via inhibiting antevocalic vowel deletion would result in restoring the special form $l o$ and not the default form $i l$.

An analogous case is the substitution of the older amalgams of preposition plus definite article pel, pello, pella, pei, pegli, pelle and col, collo, colla, coi, cogli, colle with, respectively, the morphotactically transparent per $i l$, per lo, per la, per $i$, per gli, per le, con il, con lo, con la, con $i$, con gli, con le 'through/with the'. Whereas forms such as per il, per $i$, per la and so on are by far the most common in contemporary Standard Italian, the prepositional amalgams col, coi are still sometimes used as alternative to the morphotactically transparent correspondents con $i l$, con lo, con $i$. 
An apparent counterexample could be the prepositional amalgams nel, nello, nella, negli, nei, nelle 'in the', as they are never substituted with their morphotactically transparent correspondents in lo, in il, in la, in gli, in $i$, in le in contemporary Standard Italian. However, because of their great opacity, these prepositional amalgams are in all probability stored as such. Since the similarity between $n e l$ and in etc. is smaller than between pel and per etc., the in- amalgams are less accessible to analogical processes (for this principle cf. Schindler 1971).

These convergent optimizations of morphotactic transparency in contemporary written Standard Italian may be due to the increasing use of Standard Italian by ever greater parts of Italian society, which have very divergent dialectal backgrounds, which renders a very transparent koiné preferable.

Note also that the infringement of the phonological naturalness occurs more often in written Standard Italian, where phonological naturalness plays a much smaller role than in spoken Standard Italian.

A third example comes from the prehistory of Italian, i.e. the initial stages of the loss of word-final $-s$ and $-m$ : as shown in Dressler (1973), the loss of word-final $-s$ and $-m$ represents two two-step natural weakening processes which resulted in generalising the phonologically unmarked state of vowel-final phonological words. But originally, at least in the 3rd century BC it was a variable rule or, in terms of Natural Phonology, a casual speech process which was maximized in the casual styles of spoken language and of low-level funeral inscriptions, whereas it was the more inhibited the more formal the style (register) became (demonstrated by the study of different formality of styles in inscriptions and in Plautinian comedies). However, in the period of Golden Classical Latin Standard of the first century before and after Christ, these casual phonostylistic processes vanished nearly completely from written documents. The reason is twofold: 1) in a sociolinguistic perspective, this is a matter of puristic standardisation and reactionary sociocultural restoration, 2) in a grammatical perspective, the loss of final $-s$ and $-m$ opacified the expression of important case endings such as Nom. and Gen.Sg., Nom., Acc., Dat. and Abl.Pl. in $-s$, Acc.Sg. and Gen.Pl. in $-m$. Increased inhibition of the opacifying phonological processes meant restoration of morphotactic transparency. Thus, similar to the previous Italian examples, markedness shifted back from morphological to phonological markedness for a while, presumably until the great morphosyntactic shifts from Latin to Proto-Romance took place.

Another example of the interplay between morphological and phonological parameters of naturalness comes from Polish. 
- Consonant-final prefixes and $w$ - and $z$ - prefixes added to verbs trigger an epenthetic vowel when a verb begins with a consonant cluster, e.g. wbiec vs. wetknać (cf. wtykać), zdać vs. ze brać (cf. zbierać). In the case when the verb begins with respectively the same consonant (i.e. $w$ - or $z$-), the resulting complex word begins with a geminate, e.g. wwieść, zsypać.

- Consonant-final prepositions and $w$ - and $z$ - prepositions preceding nouns generally do not require an epenthetic vowel before a cluster, thus $w$ biegu and $w$ tkaniu, $z$ Daniq and $z$ broniq. However, when the noun begins with the same consonant, i.e. respectively, $w$ - or $z$-, followed by another consonant in a cluster, an epenthetic vowel is triggered, e.g. we Wroclawiu, ze złotem. In the context of a noun-initial single $w$ - or $z$-, geminates result, as in the case of the prefixes, e.g. $w$ Warszawie, $z$ sobq.

Both multiple initial clusters and initial geminates resulting from the above morphological operations are phonologically marked; geminates, however, are relatively more marked than clusters in this position (cf. the universal phonotactic preferences). Still, geminates seem to be tolerated better than clusters, although in the case of prepositions, clusters are also tolerated (with the exception of those triples which would start with a geminate, if it weren't for the epenthesis, as in we Wroctawiu). Interestingly, geminates are also worse from the point of view of morphology, since the boundary between a prefix or preposition and a base word following it is blurred in them. This results in the decrease of morphotactic transparency. The geminate-initial structures are thus relatively marked both in phonology and morphology. Now what happens in the pronunciation of many Poles in the case of the second operation (i.e. in preposition+noun structures) is that they epenthesize a vowel in we Warszawie, ze sobq. This variation shows that markedness is not tolerated by everybody and that the structure is marked, in the first place. It is marked on the parameter referring to biuniqueness, since the allomorphy $w$-/we-, $z$-/ze- conflicts with the principle of biuniqueness (and distorts uniformity). Interestingly, prefixed structures are not "corrected" (on the one hand, wwieść must be kept different from wywieść, still *wewieść could be used, in analogy to we Warszawie, but is not). Thus, markedness is tolerated better across a word-internal morphological boundary than across a clitic boundary, although both structures are phonological words. This is because the transparency of clitic words (and word boundaries) is more important than the transparency of affixes (and affix boundaries). It 
also points to the priority of morphological naturalness over phonological naturalness, in accordance with the predictions of natural linguistics.

\section{Marked options in acquisition}

An important domain for the study of the rise of markedness is diachronic change which originates in scenarios of early phases of language acquisition (cf. Dressler 1997a). The first phenomenon that we are going to expound is morphological hypercharacterisation. This phenomenon consists in the reenforcement of a morphological marker by a synonymous (or even (paen)identical) second marker, exemplified by colloquial Spanish plurals such as:

(3) pie-s-es 'feet', café-s-es 'coffee-s' (Malkiel 1957: 79, 98f)

Morphological hypercharacterisation is a marked phenomenon insofar as there is double exponency of the plural and thus a violation of biuniqueness. In this case, the motivation of hypercharacterisation is of a prosodic nature: normally, the Spanish plural suffix $-s$ is preceded by an unstressed vowel $-o,-a$ or $-e$, as in:

(4) pez 'fish', Pl. pec-es, pared 'wall', Pl. pared-es

Therefore the second, hypercharacteristic $-s$ with automatic insertion of /e/ restores prosodic normalcy.

The same holds for the Old Latin 3.Pl.Pres. da-n-unt, byform of Classical da-nt 'they give', cf. am-a-nt, cred-unt 'they love/believe'.

In the diachronic changes

(5) Lat. es-se 'to be' > It. esse-re, Fr. être; E. Pl. child-er > child-r-en

we find another motivation: the "hypercharacteristic" final suffix was at the time of its addition a productive morphological marker, whereas the preceding marker for the same category had become unproductive. Thus the first suffix is, at best, a minor marker, whereas the second marker is the main, and soon the only recurrent and thus identifiable marker.

Such hypercharacterization is well attested in an intermediary stage of first language acquisition (cf. MacWhinney 1985: 1102, 1126), e.g. in English-learning children's plural feet-s (directly comparable with German adult Fü̈ $\beta$-e), cf. for Austrian German children:

(6) Auto-s-en, Erbs-i-s-en, Ball-i-s-en

adult: Auto-s, Erbs-e-n (dim. Erbs-i-s), Bäll-e (dim. Ball-i-s)

'car-s, pea-s, ball-s' 
These hypercharacteristic markings occur in an acquisition phase where $-(e) n$ plurals have become productive, whereas $-s$ plurals not yet (cf. Vollmann et al. 1997).

Thus if we look closer at morphological hypercharacterisation, then we can say that it is an imprecise concept that is only justified in a very superficial morphotactic or panchronic perspective. In a more precise synchronic analysis, in all cases shown, the socalled "hypercharacteristic" second marker is in fact the only "characteristic marker" in the sense of productivity and generality. The preceding first marker is an unproductive or otherwise exceptional marker and thus difficult to identify in parsing. Therefore double exponency and thus morphological markedness is only apparent. The addition of the "hypercharacteristic" marker is a natural, thus unmarked, replacement of an unproductive or exceptional marker by the corresponding productive and/or general marker. In a diachronic perspective we find here a shift of the functional load from the first to the second marker and a compensating counteraction against phonetic attrition, i.e. phonological shortening of word shapes.

How are other marked morphological options acquired? Let us take the example of German strong verbs, which represent the marked, non-default macroclass in contrast to weak verbs which form the unmarked, default macroclass. What we were able to study best, is past participle formation. Their properties are, similar to English: the constitutive property of using the suffix $-(e) n$ instead of $-(e) t$; the typical property of several microclasses to have an ablaut (apophony) in the participles, e.g.:

(7) Inf. reit-en 'to ride', strong PP ge-ritt-en vs. Inf. leit-en 'to lead', weak PP ge-leit-et.

Austrian (like German) children acquire their first PPs as rote-learnt, i.e. entire stored forms without morphological analysis. Then they extract and acquire the transparent and productive pattern of weak verb PP formation and overgeneralise it to weak verbs (cf. Vollmann et al. 1997), such as:

$$
\begin{aligned}
& \text { ge-wasch-t } \leftarrow \text { ge-wasch-en 'wash-ed', ge-geb-t } \leftarrow \text { ge-geb-en } \\
& \text { 'giv-en' }
\end{aligned}
$$

But soon they also identify and overgeneralise the allomorphic suffix $-(e) n$, as in:

$$
\text { ge-bohr-en } \leftarrow \text { ge-bohr-t 'drill-ed' }
$$


However they do not yet acquire ablaut alternation (cf. Lindner 1998) and thus eliminate ablaut, as in:

(10) ge-schneid-en $\leftarrow$ ge-schnitt-en, Inf. schneid-en 'to cut'

Only later they acquire the minor rules of ablaut alternation in German strong verb microclasses. What can we conclude from this order of acquisition?

- Marked options are acquired after unmarked options, i.e. productive -(e)t before unproductive -(e)n and transparent lack of ablaut before opaque and modificatory ablaut.

- $\quad$ As morphology, during the acquisition process, gets richer and more complex, children are induced to extract generalisations from the increasing stock of rote-learnt forms, e.g. from the alternations in

$\begin{array}{lll} & \text { Inf. } & \text { PP } \\ \text { 'to ride' } & \text { reit-en } & \text { ge-ritt-en } \\ \text { 'to quarrel' } & \text { streit-en } & \text { ge-stritt-en } \\ \text { 'to cut' } & \text { schneid-en } & \text { ge-schnitt-en } \\ \text { 'to suffer' } & \text { leid-en } & \text { ge-litt-en }\end{array}$

they induce the generalisation Pres. -ei- vs. PP - $i-$, accompanied by consonant modification, i.e. unvoicing of voiced dentals. In other words, in order to make any morphological sense of lexically stored parallel forms, they must reconstruct marked morphological rules.

\section{Conclusion}

This last example leads us directly to the general source of markedness: the dynamics of complexity. Whenever a linguistic subsystem becomes more complex, the introduction of markedness is necessarily involved. This is unavoidable both in language acquisition and in interactions between different linguistic subsystems. This is the case in conflicts between phonology and morphology, in conflicts between morphological principles of different inflectional classes and in conflicts between different phonological registers.

Sources of markedness can be conceived of either in an evolutionary or in a diachronic perspective. While refraining from speculations about the phylogenesis of markedness within the necessary increase of complexity in the evolution of language, we want to stress that the diachronic perspective can be best understood in relating it to the "locus" of origin and spread of markedness. For this purpose we can use the concept of "scenario of language change", as proposed in Dressler 
(1997a): the changes in Italian verb morphology (section 3 above) and the sources of morphological hypercharacterization (section 5) can be "localized" in the scenario of pre-school stages of children's language acquisition. Of course, hypercharacterization in learned vocabulary, such as E. datum, $\mathrm{Pl}$. data $>$ datas ( $\rightarrow$ new singular data via backformation) and ongoing change in G. Lexikon, Pl. Lexika > Lexikas (and still more negatively sanctioned, rarely pronounced, substandard Pl. Lexikan) originate much later in adolescent acquisition of Latinate morphology. The acquisition of marked strong verbs in Germanic languages, briefly mentioned in section 5, usually leads to diachronic decrease of markedness (i.e. replacement of strong-verb inflection by weak-verb inflection, rarely the other way round - in the case of rime-words, e.g. G. preisen 'to praise', weak preterite preis-te $>$ strong preterite pries, after weisen 'to indicate', wies.

Such scenarios of change can also be located in pre-school acquisition, as well as the interactions between phonology and morphology (discussed in section 4) which lead to greater morphological opacity. Those interactions, however, which result in greater morphological opacity probably originate in adolescent and adult speech. Phonostylistic change (discussed in section 2) is a phenomenon of spread which may occur in several periods of the life-time of speakers. Finally, the textual development of titles (mentioned in section 1), is a phenomenon of adult learned creativity. Thus, sources of markedness are varied as much as the increase of complexity itself.

WOLFGANG U. DRESSLER

Institute of Linguistics

University of Vienna

Berggasse 11

A-1090 VIENNA

AUSTRIA

wolfgang.dressler@ling.univie.ac.at

KATARZYNA DZIUBALSKA-KOEACZYK

School of English

Adam Mickiewicz University

al. Niepodlegtości 4

61-874 POZNAŃ

POLAND

dkasia@ifa.amu.edu.pl 
ROSSELLA SPINA

Alejandro Serani Norte 9426

VITACURA - SANTIAGO

CHILE

rossellaspina@inwind.it

\section{REFERENCES}

Alinei, Mario

1968 Spogli elettronici dell'italiano delle origini e del Duecento. The Hague: Mouton.

Angelet, Charles et al. (eds.)

1983 Langue, dialecte, littérature. Etudes romanes à la mémoire de Hugo Planteux. Leuven: Leuven University Press.

Baayen, Harald - Cristina Burani - Robert Schreuder

1997 "Effects of semantic markedness in the processing of regular nominal singulars and plurals in Italian", in: Geert Booij - Jaap van Marle (eds.), 13-33.

Bar-Yam, Jay

2000 Dynamics of complex systems. London: Longman.

Benincà, Paola - Alberto Mioni - Laura Vanelli (eds.)

1999 Fonologia e morfologia dell'italiano e dei dialetti d'Italia, Atti del XXXI Congresso della Società di Linguistica Italiana. Roma: Bulzoni.

Bittner, Dagmar - Wolfgang U. Dressler - Marianne Kilani-Schoch (eds.) 2000 "First verbs: On the way to mini-paradigms", ZAS Papers in Linguistics 18.

Booij Geert - Jaap van Marle (eds.)

1991 Yearbook of morphology. Kluwer.

1996 Yearbook of morphology. Kluwer.

Castellani, Arrigo

1952 Nuovi testi fiorentini del Dugento. Firenze: Sansoni.

Clahsen, Harald

1999 "Lexical entries and rules of language: A multidisciplinary study of German inflection", Behavioral and Brain Sciences 22/6: 991-1060.

Clahsen, Harald - Sonia Eisenbeiss - Ingrid Sonnenstuhl-Henning 1997 "Morphological structure and the processing of inflected words", Theoretical Linguistics 23/3: 201-248. 
Clahsen, Harald - Monika Rothweiler - Andreas Woest - Gary Marcus 1992 "Regular and irregular inflection in the acquisition of German noun plurals", Cognition 45: 225-255.

Cortelazzo Manlio (ed.).

1976 Profilo dei dialetti italiani vol. 9. Pisa: Pacini.

1977 Profilo dei dialetti italiani vol. 21. Pisa: Pacini.

1979a Profilo dei dialetti italiani vol. 5. Pisa: Pacini.

1979b Profilo dei dialetti italiani vol. 13. Pisa: Pacini.

Coveri, Lorenzo - Antonella Benucci - Paolo Disdori

1998 Le varietà dell'italiano. Manuale di sociolinguistica italiana. Roma: Bonacci.

Dalbera-Stefanaggi, Maria-José

1997 "Corsica", in: Martin Maiden - Mair Parry (eds.), 303-310.

Dardano, Maurizio - Pietro Trifone

1985 La lingua italiana. Bologna: Zanichelli.

Dressler, Wolfgang U.

1973 "Pour une stylistique phonologique du latin. A propos des styles négligents d'une langue morte", BSL 78: 129-145.

1984a "Explaining Natural Phonology", Phonology Yearbook 1: 29-51.

1984b "On the definite Austrian and Italian articles", in: Edmund Gussmann (ed.), 35-45.

1985a Morphonology. Ann Arbor: Karoma.

1985b "Typological aspects of Natural Morphology", Wiener Linguistische Gazette 35-36: 3-26.

1995 "Wealth and poverty of functional analyses with special reference to functional deficiencies", in: Sh. Miller - J. Mey (eds.), 11-39.

1996 "Parallelisms between Natural Text Linguistics and other components of Natural Linguistics", Sprachtypologie und Universalienforschung 49: 295-311.

1997a " 'Scenario' as a concept for the functional explanation of language change", in: J. Gvozdanović (ed.), 109-142.

1997b "On productivity and potentiality in inflectional morphology", CLASNET working papers 7.

1999 "Ricchezza e complessità morfologica", in: Paola Benincà - Alberto Mioni - Laura Vanelli (eds.), 587-597. 
Dressler, Wolfgang U. - Katarzyna Dziubalska-Kołaczyk

1994 "Functional analysis in the study of second language acquisition", Functions of Language 1: 201-228.

Dressler, Wolfgang U. et al.

2001 "The processing of interfixed German compounds", Yearbook of Morphology 1999: 185-220.

Dressler, Wolfgang U. - Wili Mayerthaler - Oswald Panagl - Wolfgang U. Wurzel

1987 Leitmotifs in natural morphology. Amsterdam-Philadelphia: Benjamins.

Dressler, Wolfgang U. - Anna Maria Thornton

1991 "Doppie basi e binarismo nella morfologia italiana", Rivista di Linguistica 3/1: 3-22.

1996 "Italian nominal inflection", Wiener Linguistische Gazette 57-59: $1-26$.

Dressler, Wolfgang U. (ed.)

1997 Studies in pre- and protomorphology. Wien: Verlag der Österreichische Akademie der Wissenschaften.

Dressler, Wolfgang U. et al. (eds.)

1984 Phonologica. Cambridge: Cambridge University Press.

Dziubalska-Kołaczyk, Katarzyna

1995 Phonology without the syllable. A Study in the Natural Framework. Poznań: Motivex.

1997 "Pre- and proto- in Polish phonology and morphology and their interrelations", in: Katarzyna Dziubalska-Kołaczyk (ed.), 1997, 159-171.

2001 "Phonotactic constraints are preferences", in: Katarzyna Dziubalska-Kołaczyk (ed.), 2001, 69-100.

in press Beats-and-binding phonology. New York: Peter Lang.

Dziubalska-Kołaczyk, Katarzyna (ed.)

1996 Naturalness within and across components. [Guest-edited volume of Sprachtypologie und Universalienforschung 49/3. Berlin: Akademie Verlag GmbH.]

1997 Pre- and protomorphology in language acquisition. [Guest-edited volume of Papers and Studies in Contrastive Linguistics 33. Poznań: NAKOM.]

2001 Constraints and preferences. (Trends in Linguistics. Studies and Monographs 134.) Berlin: Mouton de Gruyter. 
Fabri, R. et al. (eds.)

1998 Models of inflection. Tübingen: Niemeyer.

Fisiak, Jacek (ed.)

1988 Historical morphology. The Hague: Mouton.

Foresti, Fabio

1988 "Italienisch: Areallinguistik V. Emilia-Romagna", in: Günther Holtus - Michael Metzeltin - Christian Schmitt (eds.), 569-593.

Forner, Werner

1997 "Liguria", in: Martin Maiden - Mair Parry (eds.), 245-252.

Frauenfelder, Uli H. - Robert Schreuder

1992 "Constraining psycholinguistic models of morphological processing and representations: the role of productivity", in: Booij, Geert - Jaap Van Marle (eds.), 1991, 165-183.

Giammarco, Ernesto

1979 “Abruzzo", in: Manlio Cortellazzo (ed.), 1979b.

Giannelli, Luciano

1976 "Toscana", in: Manlio Cortellazzo (ed.), 1976.

Giannelli, Luciano

1988 "Italienisch: Areallinguistik VI. Toscana", in: Günther Holtus - Michael Metzeltin - Christian Schmitt (eds.), 594-605.

Górska, Elżbieta

1999 On parts and wholes. A cognitive study of English schematic part terms. Warszawa: Zakład Graficzny Uniwersytetu Warszawskiego.

Gussmann, Edmund (ed.)

1984 Phono-morphology. Lublin: Catholic University.

Gvozdanović, J. (ed.)

1997 Functional explanations in historical linguistics. Amsterdam: Benjamins.

Hajek, John

1997 "Emilia-Romagna", in: Martin Maiden - Mair Parry (eds.), 271-278.

Holtus, Günther - Michael Metzeltin - Christian Schmitt (eds.)

1988 Lexicon der romanistischen Linguistik. Band IV. Italienisch. Tübingen: Niemeyer. 
Hurch, Bernhard - Richard Rhodes (eds.)

1996 Natural phonology: The state of the art. Berlin: Mouton de Gruyter.

Jaberg, Karl - Jakob Jud

1928-1940 Sprach- und Sachatlas Italiens und der Südschweiz. Zofingen: Ringier.

Kilani-Schoch, Marianne

$1988 \quad$ Introduction à la morphologie naturelle. Bern: Lang.

Lemke, Jay

1999 Opening up closure: Semiotics across scales. [MS for: Chandler, Jerry - Gertrudis Van de Vijver (eds.), Closure: Emergent organizations and their dynamics. Annals of the New York Academy of Sciences, volume 901. New York: The New York Academy of Sciences.]

Lindner, Katrin

1998 "Overgeneralization revisited: the case of German past participles", in: R. Fabri et al. (eds.), 152-174.

Lima, Susan D. - Roberta L. Corrigan - Gregory K. Iverson (eds.)

1994 The reality of linguistic rules. Amsterdam: Benjamins.

Lipka, L. (ed.)

1981 Wortbildung. Darmstadt: Wissenschaftliche Buchgesellschaft.

Loporcaro, Michele

1988 Grammatica storica del dialetto di Altamura. Pisa: Giardini.

1997 Puglia and Salento, in: Martin Maiden - Mair Parry (eds.), 338-348.

Luelsdorff, Paul (ed.)

1994 The Prague school of structural and functional linguistics. Amsterdam - Philadelphia: Benjamins.

Lurati, Ottavio

1988

"Italienisch: Areallinguistik III. Lombardei und Tessin", in: Günther Holtus - Michael Metzeltin - Christian Schmitt (eds.), 485-516.

Lüdtke, Helmut

1979 "Lucania", in: Manlio Cortellazzo (ed.), 1979a. 
MacWhinney, Brian

1985 "Hungarian language acquisition as an exemplification of a general model of grammatical development", in: D.I. Slobin (ed.), 1069-1155.

Maddieson, Ian

1999

"In search of universals", in: John J. Ohala et al. (eds.), 2521-2528.

Madelska, Liliana

1987

Mowa spontaniczna. Analiza wariantywnoœci fonetycznej w wymowie studentów UAM. [Unpublished Ph.D. dissertation, Adam Mickiewicz University, Poznań.]

Magni, Elisabetta

1997

"L'organizzazione dei paradigmi nella flessione rizotonica e il passato remoto di avere e sapere in italiano", Rendiconti morali dell'Accademia dei Lincei 9/8: 119-146.

Maiden, Martin

1995 A linguistic history of Italian. New York: Longman.

Maiden, Martin - Mair Parry (eds.)

1997 The dialects of Italy. London: Routledge.

Makovec-Černe, Jasna - Wolfgang U. Dressler

1997 On the acquisition of Slovene verb inflection, in:

Wolfgang U. Dressler (ed.), 1997, 115-126.

Malkiel, Yakov

1957 "Diachronic hypercharacterization in Romance", Archivum

Linguisticum 9: 79-113, 10: 1-36.

Marinucci, Marcello

1988 "Italienisch. Areallinguistik VIII. Abruzzen und Molisen", in: Günther Holtus - Michael Metzeltin - Christian Schmitt (eds.), 643-652.

Melillo, Matteo

1977 "Corsica", in: Manlio Cortellazzo (ed.), 1977.

Miller, Sh. - J. Mey (eds.)

1995 Form and function in language. Odense: Odense University Press.

Monaci, Ernesto - Arese Felice

1955 Crestomazia italiana dei primi secoli. Roma-Napoli: Dante Alighieri. 
Motsch, Wolfgang

1981 "Der kreative Aspekt in der Wortbildung", in: L. Lipka (ed.), 94-118.

Negroni, Carlo (ed.)

1885 La Bibbia volgare, sec. XIV, vol. VI, Commissione per i testi di lingua. Bologna: Romagnoli.

Nesi, Annalisa

1988 "Korsisch: Interne Sprachgeschichte", in: Günther Holtus - Michael Metzeltin - Christian Schmitt (eds.), 799-808.

Ohala, John J. et al. (eds.)

1999

Proceedings of the 14th International Congress of Phonetic Sciences: San Francisco, August 1999, vol. 3.

Pasquarelli Clivio, Mirella

1994 La formazione storica del perfetto forte nell'Italia meridionale. Roma: Bulzoni.

Pinker, Steven - Alan Prince

$1994 \quad$ "Regular and irregular morphology and the psychological status of rules in grammar", in: Susan D. Lima - Roberta L. Corrigan - Gregory K. Iverson (eds.), 321-351.

Pöchtrager, Markus A. - Csanád Bodó - Wolfgang U. Dressler - Theresa Schweiger

1998 "On some inflectional properties of the agglutinating type illustrated from Finnish, Hungarian and Turkish inflection", Wiener Linguistische Gazette 59-91.

Prigogine, Ilija

1961 Introduction to the thermodynamics of irreversible processes. New York: Interscience.

Radtke, Edgar

1988

"Italienisch: Areallinguistik IX. Kampanien, Kalabrien", in: Günther Holtus - Michael Metzeltin - Christian Schmitt (eds.), 652-660.

Rohlfs, Gerhard

1968 Grammatica storica della lingua italiana e dei suoi dialetti. Morfologia. Torino: Einaudi.

Sanga, Glauco

1997

"Lombardy", in: Martin Maiden - Mair Parry (eds.), 253-259. 
Savoia, Leonardo

1997 "Inflectional morphology of the verb", in: Maiden Martin - Mair Parry (eds.), 75-86.

Say, Thessa - Harald Clahsen

2000 Words, rules and stems in the Italian mental lexicon. [Poster presented at the $9^{\text {th }}$ International Morphology Meeting, Vienna, February 25-27, 2000.]

Schiaffini, Alfredo

1926 Testi fiorentini del Dugento e dei primi del Trecento. Firenze: Sansoni.

Serianni, Luca

1991 Grammatica italiana. Italiano comune e lingua letteraria. Torino: Utet.

Serianni, Luca

1995

"Toscana, Korsika", in: Günther Holtus - Michael Metzeltin - Christian Schmitt (eds.), 135-150.

Singh, Rajendra

1987

"Well-formedness conditions and phonological theory", in: Wolfgang U. Dressler et al. (eds.), 273-285.

Singh, Rajendra (ed.)

1994 Trubetzkoy's Orphan. Amsterdam: Benjamins.

Skalička, Vladimir - Petr Sgall

1994 "Praguian typology of languages", in: Paul Luelsdorff (ed.), 333-357.

Slobin, D. I. (ed.)

1985

The crosslinguistic study of language acquisition 2. Hillsdale: Erlbaum.

Stuart, Charles

1984 Manuale di radiologia medica. Padova: Piccin.

Tekavčić, Pavao

1980 Grammatica storica della lingua italiana. II: Morfosintassi. Torino: Einaudi.

Vanvolsem, Sylvain

1983 "Il regresso dell'elisione nell'italiano moderno", in: Charles Angelet et al. (eds.), 159-161. 
Väänänen, Veikko

1982 Introduzione al latino volgare. Bologna: Patron. III ed. (Italian translation of Väänänen, V. 1967. Introduction au latin vulgaire. Paris: Klincksieck, $2^{\text {nd }}$ ed.).

Vincent, Nigel

1980

"Words versus morphemes in morphological change: The case of the italian -iamo", in: Jacek Fisiak (ed.), 393-98.

Vineis, Edoardo

1974 Studio sulla lingua dell'Itala. Pisa: Pacini.

Wanner, Dietrich

1975 "Die historische Motivierung der Endung -iamo im Italienisch", Zeitschrift für romanische Philologie 91: 153-175.

Wurzel, Wolfgang U.

1980 "Way of morphologizing phonological rules", in: Jacek Fisiak (ed.), 443-462.

Wurzel, Wolfgang U.

1984 Flexionsmorphologie und Natürlichkeit. Berlin: AkademieVerlag.

Zamboni, Alberto

1988 "Italienisch: Areallinguistik IV. A) Venezien. Veneto", in: Günther Holtus - Michael Metzeltin - Christian Schmitt (eds.), 517-538.

Zurek, Wojciech H. (ed.)

1990 Complexity, entropy and the physics of information. Redwood City: Addison Wesly. 
Brought to you by | Vienna University Library/Universitaet Wien Authenticated | 77.80.49.244

Download Date | 6/4/13 11:04 AM 